\title{
Customer And Market Orientation Within AACSB Member Business Schools: Comparative Views From Three Levels Of Administrators
}

Robert L. Webster, Ouachita Baptist University, USA

Kevin L. Hammond, University of Tennessee at Martin, USA

James C. Rothwell, Ouachita Baptist University, USA

\begin{abstract}
This paper is part of a stream of research dealing with customer and market orientation within higher education, specifically within business schools holding membership in AACSBInternational. A market orientation strategy leading to a customer and market-oriented organizational culture is based upon the acceptance and adoption of the marketing concept. The market-oriented organization recognizes the importance of coordinating the activities of all departments, functions, and individuals in the organization to satisfy customers by delivering superior value. The market-oriented organization continually monitors customer information, competitor information, and marketplace information to design and provide superior value to its customers. Theory and empirical research suggest that higher levels of customer and market orientation result in a greater ability of the organization to reach its objectives, in other words, higher levels of organizational performance. This paper extends the current research on the use of the market orientation strategy by reporting and analyzing customer and market orientation levels (scores) toward two customer groups within AACSB member business schools. The two customer groups studied were students and employers of students. Data input from three separate administrative levels having responsibilities associated with the business school were collected and analyzed. The administrators participating in the study were academic vice-presidents, business school deans and marketing department chairs. A critical underlying question in the research is whether students and employers of students are viewed as customers by higher education administrators. Comparisons of the various reported scores are made against a benchmark established in the marketing literature and then are compared by administrative group against one another. The university academic vice-presidents, business school deans, and marketing department chairs were surveyed by way of a national mail survey. All administrators were from colleges or universities holding membership in AACSB-International. 102 VicePresidents, 141 Business School Deans, and 94 Marketing Department Chairs responded. The paper presents details of the research process, findings, statistical inferences, and discusses the implications of the research for schools of business and academic marketing departments.
\end{abstract}

Keywords: Customer orientation, market orientation, higher education performance

\section{INTRODUCTION AND DEFINITIONS}

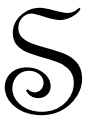

uccessful organizations seek to attain and maintain high levels of performance; but can a particular organizational strategy or culture lead to improved organizational performance? If so, can such a strategy or culture be described and then be measured quantitatively? And, if measurements can be made will comparisons in measurements between organizations be advantageous in helping organizations improve their performance? 
This paper investigates these questions, measures a specific component of organizational strategy and compares three managerial levels of educational organizations. The organizational strategy measured is market orientation. The quantitative measurement is accomplished by way of a scaled instrument used in a national survey. The comparisons described in this research include benchmarked levels between commercial businesses (for profit entities) and various organizational levels of schools of business administration (non-profit entities).

In marketing literature, numerous similar sounding terms are often encountered. These terms are not synonymous and should not be used interchangeably. To help differentiate and explain terms, the following descriptions and definitions are provided:

- $\quad$ The marketing concept is a philosophy that advocates that a successful organization begins with identifying customer needs and wants, decides which needs to meet, and involves all employees in the process of satisfying customers.

- $\quad$ Marketing orientation implies that the marketing function is the most important function within the organization and that all other functional areas are driven by the demands of the marketing department.

- Market orientation refers to an organizational culture in which everyone in the organization is committed to the customer and adapts in a timely manner to meeting the changing needs of the customer. Market orientation blends a company culture dedicated to providing superior value by successfully achieving a customer focus, acquiring competitor intelligence, and maintaining interfunctional coordination. It is viewed as the implementation of the marketing concept.

\section{DISCUSSION AND LITERATURE REVIEW}

The Baldrige Education Criteria for Performance Excellence, developed by the Baldrige National Quality Program (BNQP 2005), rest on the assumption that universities can take steps to achieve "performance excellence". The document specifies certain marketing-related activities, and emphasizes the need to identify and plan strategies with respect to various segments of students, stakeholders and other markets. The Baldrige criteria are designed to be used for self-assessment, awarding Baldrige prizes, and providing feedback to educational institutions applying for them, but have other important purposes as well. They can be used by any university business school, for example, regardless of whether or not it is an award applicant, to "improve organizational performance practices, capabilities, and results," to "facilitate ... sharing of best practices," and to assist in "understanding and managing performance ... guiding organizational planning and opportunities for learning" (BNQP 2005).

Excellence of performance in higher education is self-evidently important. In the business discipline, it is assessed and assured by the qualification standards of the bodies awarding formal accreditation to business schools (Karathanos and Karathanos 1996). In the U.S.A., these are mainly AACSB International (the Association to Advance Collegiate Schools of Business, known until 1997 as the American Assembly of Collegiate Schools of Business) and ACBSP (the Association of Collegiate Business Schools and Programs), address performance evaluation and improvement. Performance is ranked more informally in the U.S.A. by the annual guide published by U.S. News and World Report and by the Peterson's web-based educational information resource, both directed at prospective students, their parents and student advisers such as high school guidance counselors.

The scope of marketing was successfully broadened decades ago to include universities and other nonbusiness organizations (Kotler and Levy 1969a, 1969b). Many other marketing academics have since discussed and demonstrated the benefits of applying marketing to services in general (Lovelock 1983; Swenson 1998) and higher education in particular (Hayes 1989; Miller et al. 1990). University business school administrations and other stakeholders should be interested in strategic marketing applications and any other actions that could have a significant impact upon performance levels. Nevertheless, the 'senior leaders' invoked in the Baldrige criteria may in principle accept the importance of quality, performance and continuous improvement, yet in practice resist the notion that academic institutions could or should consider students as customers.

The study reported here, part of a stream of continuing research, and is a further effort to encourage the application of strategic marketing theory and practice within higher education. We know, from previous empirical research (Hammond et al. 2006) that the behaviours and actions indicative of a high level of market orientation 
generally lead to higher levels of performance within university business schools. The research further indicates that emphasis by higher education leaders can positively impact market orientation levels. We also know that market orientation levels reported for private business schools are generally higher than those reported for public business schools (Webster et al. 2005).

The marketing concept advocates that all activities of a firm should be directed toward satisfying the customer. The market orientation construct has been developed, defined and measured to operationalize the implementation of the marketing concept. Narver \& Slater (1990) and Kohli \& Jaworski (1993) concluded that market orientation is the type of business culture and climate that can be created within an organization that will most effectively lead to the behaviors and actions necessary to achieve a sustainable competitive advantage. The degree that the marketing concept has been implemented is manifested in the behaviors and actions of the organization. This degree is the level of market orientation. Or simply, the methods and strategies utilized by a firm to succeed.

Narver \& Slater (1990) describe a firm that is market oriented as one whose culture is systematically and entirely committed to the continuous creation of superior value for its customers. Others characterize a market orientation culture as one in which a business focuses on customer wants and needs, continuously analyzes its competition, and coordinates all organizational activities toward customer satisfaction (Kotler 1980; Narver et al. 1992; Slater \& Narver 1994; Siguaw et al. 1994). Theory suggests and empirical research has found that greater levels of market orientation within a business result in a greater ability of the organization to achieve its objectives (Barksdale \& Darden 1971; Houston 1986; Kohli \& Jaworski 1990; Narver \& Slater 1990; Jaworski \& Kohli 1993; Siguaw et al. 1994). Research to date however has only recently begun to address market orientation measurements in non-profit organizations such as universities (Webster et al. 2005; Hammond et al. 2006).

A high degree of market orientation indicates that individuals in the organization are committed to customer satisfaction and remain so over time by recognizing changes in customer needs and wants, and reacting and adapting in a satisfactory manner to those changes. The process is dynamic and subject to forces external to the organization such as its competitors and the general state of the economy, and it is a process that should be viewed on a continuum. In other words, it is not a culture that a business either has or does not have, but is rather a matter of degree. Slater \& Narver (1994) note that market conditions and competitive threats are never static; and, a high degree of market orientation is not achieved overnight but rather over time given adequate commitment from the firm's management and time for a supportive culture to develop.

For decades the philosophy expressed by managers was a belief in the practical importance of a successful marketing function as an effective way to help the organization to achieve its objectives (Felton 1959; Levitt 1969; McNamara 1972). More recently, researchers have found that greater levels of market orientation result in a greater organizational ability to achieve its objectives (Houston 1986; Narver \& Slater 1990; Jaworski \& Kohli 1993; Kohli \& Jaworski 1993; Siguaw et al. 1994). The measurement of market orientation in the business organization was pioneered by Narver \& Slater (1990). Drawing from theoretical research, they operationalized the market orientation construct as consisting of three separate and equally important components: (1) customer orientation, (2) competitor orientation, and (3) interfunctional coordination. Narver \& Slater (1990) reported market orientation scores for three separate types of businesses: commodity, specialty, and distribution. The commodity and distribution businesses produced and sold generic products designed for a wide range of customers. The specialty business firms produced and sold products that were individualized (relative to the commodity products) for specific customer orders. By adapting its generic or base product, the specialty products firm creates superior value and thereby provides more benefit to the customer. They created multiple item scales for the measurement of each of the components. The scales included antecedent variables, moderator variables, and consequence variables, e.g., performance. Finally, the scale measured overall market orientation by averaging the three components or dimensions of the measurement scale.

To date, empirical research on the market orientation culture has been primarily focused on the business enterprise with less emphasis on potential applications in non-profit organizations. Non-profit organizations such as churches, civic organizations, universities, and hospitals focus on customers or clientele wants and needs just as the business concern does. Given that successful businesses report higher levels of market orientation, we might expect 
a similar situation to be present in non-profit organizations as well. From a large group of potential non-profit organizations, we chose certain Schools of Business Administration to research because of their seeming similarities to business enterprises. Specifically, a school of business has a number of constituencies to serve, it must determine wants and needs of its clientele, it operates to provide value to its constituencies, it is influenced by external factors, and it is an organization with many interfunctional areas and departments. Although a school of business administration does not exist to create profit or shareholder wealth, it does seek to achieve organizational goals such as surviving as an organization, increasing its professional reputation, improving its facilities and faculty, and growing its enrollment and endowment. Additionally, business schools teach the principles, methods, and techniques used by businesses in their pursuit of success and business school deans and faculty often have a business background. These factors tend to suggest that business school leaders (academic vice-presidents, deans and department chairs) and business leaders (managers) may possess similar managerial mindsets, values, and temperaments as well as implementing somewhat similar leadership styles, methods and techniques.

Recalling that the philosophy of providing superior value to customers (relative to competitors) is the marketing concept, this philosophy should be applicable to universities as they too have customers, competitors, external influences, and seek to accomplish organizational goals. Although the primary objective for the business enterprise is profitability, Slater \& Narver (1994) argue that in the non-profit organization, survival is analogous to profit in a business enterprise. Specifically, to satisfy constituencies in the long run requires that revenues must be adequate to cover long-run expenses and therefore survive. Like the business enterprise, the non-profit entity has organizational objectives that is seeks to achieve.

As in the profit-seeking business, quality, performance, and continuous improvement are objectives of schools of business administration both in the short-term and the long-term. Progress in achieving such objectives is part of the evaluative process addressed by the Baldrige Education Pilot Criteria (Karathanos \& Karathanos 1996) and the AACSB--International Standards. Also, U.S. News and World Report and Peterson's College Guide as well as other publications issue annual college guides that provide various measures of performance to assist students and parents in the college selection process. Consequently, the leaders of schools of business administration should be interested in an organizational culture that could positively impact the quality and performance of their schools. This research, which is part of a continuing stream of research focused on marketing theory and practice found in higher education, collects, analyzes and reports on the market orientation culture within schools of business administration that are members of AACSB-International.

Academic Vice-Presidents, Business School Deans, and Marketing Department chairs whose school hold membership in AACSB-International were selected for study because the accrediting organization holds to a commitment of continuous improvement in business education. Schools that are accredited by AACSBInternational have undergone a series of reviews over time, have demonstrated success at achieving organizational goals, and therefore may exhibit an organizational culture with a bent toward market orientation, much like that of successful businesses.

\section{RESEARCH QUESTIONS AND HYPOTHESIS}

Although there are numerous customers or stakeholders that could be addressed in the university setting, we limited our examination to marketing majors and other business students. The objectives of the study were to answer the following research questions:

1. What are the mean levels of market orientation toward students and employers of students (customer groups) of schools of business administration as reported by academic vice-presidents?

2. What are the mean levels of market orientation toward students and employers of students (customer groups) of schools of business administration as reported by business school deans?

3. What are the mean levels of market orientation toward students and employers of students (customer groups) of schools of business administration as reported by marketing department chairs?

4. How do the reported mean levels of market orientation toward students and employers of students of the academic vice-presidents, deans, and marketing chairs compare to the levels reported toward customers as reported by business managers from previous research conducted on businesses in the private sector? 
5. How to the mean levels of market orientation toward students and employers of students reported by the academic vice-presidents, deans, and marketing department chairs compare to each other as groups?

To answer research question one, the reported market orientation mean scores of the academic vicepresidents were collected and calculated from the survey responses for the four dimensions of market orientation (customer orientation, competitor orientation, internal coordination, and overall market orientation).

To answer research question two, the reported market orientation mean scores of the business school deans were collected and calculated from the survey responses for the four dimensions of market orientation (customer orientation, competitor orientation, internal coordination, and overall market orientation).

To answer research question three, the reported market orientation mean scores of the marketing chairs were collected and calculated from the survey responses for the four dimensions of market orientation (customer orientation, competitor orientation, internal coordination, and overall market orientation).

To answer research question four, the mean market orientation scores of the academic vice-presidents, business school deans, and marketing department chairs were compared to the mean market orientation scores of specialty business managers as reported by Narver and Slater (1990). The general hypothesis was than there was no difference between the market orientation scores of the business mangers and the academic vice-presidents, deans and department chairs. This general hypothesis was tested by way of a series of t-tests that compared mean scores of the academic vice-presidents, deans, and marketing department chairs to those of the business managers. For each comparison, t-tests were conducted separately on the four components of market orientation.

To answer research question five, the mean market orientation scores of the academic vice-presidents, deans, and marketing department chairs were compared to each other using a series of t-tests to identify differences in mean scores between the various groups of administrators for each of the four dimensions of market orientation. Again, the general hypothesis was that there would be no statistical difference between the mean scores of the administrators.

\section{METHODOLOGY}

A cover letter, survey instrument, and business reply envelope were mailed separately to the academic vicepresidents, business school deans, and to the marketing chairs of schools of business holding membership in AACSB-International. After a follow-up letter, 102 useable responses were received from the academic vicepresidents, 141 responses from the deans and 94 responses from the marketing department chairs. As key informants, (Campbell 1995; Phillips 1981), the vice-presidents, deans, and department chairs were asked to complete the survey and return it in the business reply envelope.

The questions to measure the three subscales (competitor orientation, customer orientation, and organizational coordination) in the Narver and Slater original scale were modified somewhat to conform to the vocabulary and the types of stakeholders prevalent in academic institutions. For example, two of Narver and Slater's questions were:

1. Our objectives are driven by satisfaction of our customers.

2. We measure satisfaction of our customers systematically and frequently.

The questions were amended for the current research and were worded as follows:

1. Our objectives are driven by satisfaction of our students/employers of students

2. We measure satisfaction of our students/employers of students systematically and frequently.

Churchill (1979) suggests that the appropriateness of scales borrowed from other studies needs to be addressed before survey research is accomplished. Therefore, all our scale items were pre-tested before mailed. We consulted with several academic vice-presidents, deans, and marketing department chairs. These consultations 
resulted in a research instrument and cover letter that more clearly defined the purposes of the research and the rewording of several questionnaire items.

30 questions were used in the collection of the data. Each of the questions were to be answered using a seven (7) point scale that was anchored with "not at all" (1) and "to an extreme extent" (7) so that the higher numbers represented a higher (or greater) perceived level of market orientation. The survey questions are shown and discussed in the appendix to the paper.

The scales were subjected to reliability analysis, exploratory factor analysis and confirmatory factor analysis prior to use (Wheaton, Muthen, Alwin, \& Summers 1997; Bentler \& Bonett 1980; Marsh \& Hocevar 1985; Bentler 1990; Browne \& Mels 1992; and Browne \& Cudeck 1993). Results of these analyses indicated satisfactory reliabilities (ranges from .73 to .91), satisfactory item-to-total correlations (ranges from 0.3 to 0.8 ), exploratory factor loadings ranging from 0.33 to 0.89 , and confirmatory factor loading ranging from 0.36 to 0.82 . Additionally, the confirmatory factor analysis demonstrated generally acceptable fit. These test results included comparative fit index measures ranging from .784 to 1.000 , a Tucker-Lewis index ranging from .702 to 1.000 , and the CMIN/DF ranging from 2.05 to 2.56 . The RMSEA low values at the $90 \%$ confidence interval fell below 0.10 for all scales.

Although the literature indicates (Berdie 1989) that the presence of nonresponse bias in mail surveys does not necessarily alter the survey findings, we nonetheless proceeded to test for nonresponse bias. We used Larson and Catton's (1959) proxy methodology wherein potential nonresponse bias between early and late respondents is examined. These tests indicated no statistically significant difference between the early and late responders.

Then, following the methodology of Narver and Slater, we combined the three subscales to form an overall, or composite, measure of market orientation. We then conducted separate t-tests for each of the four dimensions of market orientation to determine if a statistically significant difference existed between the various market orientation mean scores of the academic vice-presidents, deans, marketing department chairs, and the business managers.

As mentioned earlier, in their 1990 research, Narver and Slater reported market orientation scores for three separate types of businesses: commodity, specialty, and distribution. We believe schools of business demonstrate more of the characteristics of specialty businesses than the characteristics of the commodity or distribution businesses. The commodity and distribution businesses in the Narver and Slater study produced and sold generic products designed for a wide range of customers. The specialty business firms produced and sold products that were individualized (relative to the commodity products) for specific customer orders. By adapting its generic or base product, the specialty products firm creates superior value and thereby provides more benefit to the customer. This type of firm is challenged to constantly monitor the competitive environment and to be vigilant for changes in the customer's requirements. Likewise AACSB-International schools of business seek to provide a product that is individualized through its programs of study or majors. The AACSB-International schools would argue that a superior product (relative to non-member schools) is provided that would benefit its customers (or constituencies). We therefore used the market orientation scores for specialty business as reported by Narver and Slater (1990) for our comparisons.

\section{RESULTS}

Table 1 shows there are significant differences in levels of customer orientation and overall market orientation between the business managers toward their customers and the business school officials (the academic vice-presidents, deans, and marketing department chairs) toward their students as a customer group. The business managers reported market orientation mean scores that were higher in absolute terms than all of the school administrators in each of the four dimensions of market orientation. Additionally, the scores were found to be statistically different at the 0.01 level in 11 of the 12 comparisons. Hence we know that there are indeed differences between business managers and business school administrators in the levels of market orientation. 
Table 1

Means and t-test Results for Marketing Department Chairs, Business School Deans and Academic Vice Presidents versus Specialty Business Managers

Market Orientation Measurements ( 7 point scale)

Customer Group: Students

\begin{tabular}{lcccc}
\hline Market Orientation Construct: & $\begin{array}{c}\text { Business } \\
\text { Managers } \\
\mathbf{n = 7 5}\end{array}$ & $\begin{array}{c}\text { Marketing } \\
\text { Chairs } \\
\mathbf{n = 9 4}\end{array}$ & $\begin{array}{c}\text { Business } \\
\text { Deans } \\
\mathbf{n = 1 4 1}\end{array}$ & $\begin{array}{c}\text { Academic } \\
\text { VPs } \\
\mathbf{n = 1 0 2}\end{array}$ \\
\hline \hline Customer Orientation & $M$ & $M$ & $M$ & $M$ \\
Competitor Orientation & 5.05 & $4.75^{*}$ & $4.55^{*}$ & $4.77^{*}$ \\
Interfunctional Coordination & 4.71 & $3.46^{*}$ & $3.71^{*}$ & $4.17^{*}$ \\
Overall Market Orientation & 4.53 & $3.98^{*}$ & $4.13^{*}$ & $4.44^{\wedge}$ \\
\hline \hline
\end{tabular}

*significant at .01 compared to Business Managers

$\wedge$ not statistically significant compared to Business Managers

Table 2 shows there are significant statistical differences in levels of market orientation between the academic vice-presidents and the business school deans. The market orientation scores for each of the four dimensions of measurement are higher in absolute terms and statistically higher for the vice-presidents than for the deans in three of the four dimensions.

Table 2

Means and t-test Results for Academic VPs and Business School Deans

Customer Group: Students

Market Orientation Measurements ( 7 point scale)

\begin{tabular}{lcccc}
\hline \hline Market Orientation Construct: & $\begin{array}{c}\text { Academic } \\
\text { VPs }\end{array}$ & $\begin{array}{c}\text { Business } \\
\text { Deans }\end{array}$ & t-value & Significance \\
\hline \hline Customer Orientation & $M$ & $M$ & & $\mathrm{~ns}$ \\
Competitor Orientation & 4.77 & 4.55 & 1.56 & $<.01$ \\
Interfunctional Coordination & 4.17 & 3.71 & 3.25 & $<.05$ \\
Overall Market Orientation & 4.44 & 4.13 & 2.30 & $<.05$ \\
\hline \hline
\end{tabular}

Table 3 reports the market orientation scores toward students reported by the academic vice-presidents and business school marketing department chairs. Additionally, the table shows t-test results for differences in the mean scores between the two groups of administrators. In these comparisons, vice-presidents were found to have higher and statistically different market orientation scores in three of the four components of market orientation.

Table 3

Means and t-test Results for Academic VPs and Marketing Departments Chairs

Customer Group: Students

Market Orientation Measurements ( 7 point scale)

\begin{tabular}{lcccc}
\hline \hline Market Orientation Construct: & $\begin{array}{c}\text { Academic } \\
\text { VPs }\end{array}$ & $\begin{array}{c}\text { Marketing } \\
\text { Chairs }\end{array}$ & t-value & Significance \\
\hline \hline Customer Orientation & $M$ & $M$ & & $\mathrm{~ns}$ \\
Competitor Orientation & 4.77 & 4.75 & 0.14 & $<.01$ \\
Interfunctional Coordination & 4.17 & 3.46 & 4.98 & $<.01$ \\
Overall Market Orientation & 4.44 & 3.98 & 2.23 & $<.01$ \\
\hline \hline
\end{tabular}


Table 4 reports the market orientation scores toward students reported by the business school deans and the marketing department chairs. The table shows that the mean scores are higher for deans than marketing department chairs in three of the four market orientation dimensions. However, in only one of the four dimensions are the scores of the deans statistically different (at 0.10 level) from the marketing department chairs.

Table 4

Means and t-test Results for Business School Deans and Marketing Departments Chairs Customer Group: Students

Market Orientation Measurements ( 7 point scale)

\begin{tabular}{lcccc}
\hline \hline Market Orientation Construct: & $\begin{array}{c}\text { Business } \\
\text { Deans }\end{array}$ & $\begin{array}{c}\text { Marketing } \\
\text { Chairs }\end{array}$ & t-value & Significance \\
\hline \hline Customer Orientation & $M$ & $M$ & 1.43 & $\mathrm{~ns}$ \\
Competitor Orientation & 4.55 & 4.75 & 1.79 & $<.10$ \\
Interfunctional Coordination & 3.71 & 3.46 & 1.08 & $\mathrm{~ns}$ \\
Overall Market Orientation & 4.13 & 3.98 & 0.50 & $\mathrm{~ns}$ \\
\hline \hline
\end{tabular}

Table 5 shows there are significant differences in levels of market orientation between the business managers toward customers and the business school officials (the academic vice-presidents, deans, and marketing department chairs) toward employers of students as a customer group. The business managers reported market orientation mean scores that were higher in absolute terms than all of the school administrators in each of the four dimensions of market orientation. Additionally, the scores were found to be statistically different at the 0.01 level in all 12 of the comparisons. Hence we know that there are indeed differences between business managers and business school administrators in the levels of reported market orientation.

Table 5

Means and t-test Results for Marketing Department Chairs, Business School Deans and Academic Vice Presidents versus Specialty Business Managers Market Orientation Measurements ( 7 point scale) Customer Group: Employers of Students

\begin{tabular}{lcccc}
\hline Market Orientation Construct: & $\begin{array}{c}\text { Business } \\
\text { Managers } \\
\mathbf{n = 7 5}\end{array}$ & $\begin{array}{c}\text { Marketing } \\
\text { Chairs } \\
\mathbf{n = 9 4}\end{array}$ & $\begin{array}{c}\text { Business } \\
\text { Deans } \\
\mathbf{n = 1 4 1}\end{array}$ & $\begin{array}{c}\text { Academic } \\
\text { VPs } \\
\mathbf{n = 1 0 2}\end{array}$ \\
\hline \hline Customer Orientation & $M$ & $M$ & $M$ & $M$ \\
Competitor Orientation & 5.05 & $3.95^{*}$ & $4.06^{*}$ & $4.51^{*}$ \\
Interfunctional Coordination & 4.71 & $3.42^{*}$ & $3.69^{*}$ & $4.11^{*}$ \\
Overall Market Orientation & 4.53 & $3.67^{*}$ & $3.91^{*}$ & $4.22^{*}$ \\
\hline \hline
\end{tabular}

*significant at .01 compared to Business Managers

Table 6 shows the market orientation scores toward employers of students as reported by the academic vice-presidents and the business school deans. The scores reported by the academic vice-presidents are higher in absolute terms than the scores of the deans in each of the four dimensions of market orientation. The market orientation scores for each of the four dimensions of measurement are statistically higher for the vice-presidents that for the deans. 
Table 6

Means and t-test Results for Academic VPs and Business School Deans

Customer Group: Employers of Students

Market Orientation Measurements (7 point scale)

\begin{tabular}{lcccc}
\hline \hline Market Orientation Construct: & $\begin{array}{c}\text { Academic } \\
\text { VPs }\end{array}$ & $\begin{array}{c}\text { Business } \\
\text { Deans }\end{array}$ & t-value & Significance \\
\hline \hline Customer Orientation & $M$ & $M$ & & \\
Competitor Orientation & 4.51 & 4.06 & 3.22 & $<.01$ \\
Interfunctional Coordination & 4.11 & 3.69 & 3.00 & $<.01$ \\
Overall Market Orientation & 4.22 & 3.91 & 2.22 & $<.05$ \\
\hline \hline
\end{tabular}

Table 7 shows the market orientation scores toward employers of students of the academic vice-presidents and business school marketing department chairs. Additionally, the table shows t-test results for differences in the mean scores between the two groups of administrators. In these comparisons, vice-presidents were found to have higher and statistically different market orientation scores in all four components of market orientation.

Table 7

Means and t-test Results for Academic VPs and Marketing Departments Chairs

Customer Group: Employers of Students Market Orientation Measurements (7 point scale)

\begin{tabular}{lcccc}
\hline \hline Market Orientation Construct: & $\begin{array}{c}\text { Academic } \\
\text { VPs }\end{array}$ & $\begin{array}{c}\text { Marketing } \\
\text { Chairs }\end{array}$ & t-value & Significance \\
\hline \hline & $M$ & $M$ & & $<.01$ \\
Customer Orientation & 4.51 & 3.95 & 3.87 & $<.01$ \\
Competitor Orientation & 4.11 & 3.42 & 4.77 & $<.01$ \\
Interfunctional Coordination & 4.22 & 3.67 & 3.80 & $<.01$ \\
Overall Market Orientation & 4.28 & 3.68 & 4.15 & \\
\hline \hline
\end{tabular}

Table 8 shows the market orientation scores toward employers of students of the business school deans and the marketing department chairs. The table shows that the mean scores are higher for deans than marketing department chairs in all four market orientation dimensions. However, in only two of the four dimensions are the scores of the deans statistically different (at 0.10 level) from the marketing department chairs.

Table 8

Means and t-test Results for Business School Deans and Marketing Departments Chairs

Customer Group: Employers of Students

Market Orientation Measurements ( 7 point scale)

\begin{tabular}{|c|c|c|c|c|}
\hline Market Orientation Construct: & $\begin{array}{c}\text { Business } \\
\text { Deans }\end{array}$ & $\begin{array}{c}\text { Marketing } \\
\text { Chairs }\end{array}$ & t-value & Significance \\
\hline & $M$ & $M$ & & \\
\hline Customer Orientation & 4.06 & 3.95 & 0.78 & ns \\
\hline Competitor Orientation & 3.69 & 3.42 & 1.92 & $<.10$ \\
\hline Interfunctional Coordination & 3.91 & 3.67 & 1.70 & $<.10$ \\
\hline Overall Market Orientation & 3.89 & 3.68 & 1.49 & ns \\
\hline
\end{tabular}

A synopsis of the 8 tables shows that business managers report higher levels of market orientation toward customers than the educational leaders report toward students and employers of students. This may be an indication that higher education administrators either do not view students and employers as customers, or that the implementation of the market concept has not been embraced within business school administrations, or both. It is particularly interesting to note that the higher up the administrator is within the higher education hierarchy, the 
higher the levels of reported market orientation toward students. This certainly indicates that the implementation or the perceived level of importance of the marketing concept differs across the various levels of higher education administration. For a strategy to be successful, the marketing theory suggests that a strategy must be implemented at all levels of the organization. This seems to be lacking in the case of business school administration.

\section{IMPLICATIONS}

These findings demonstrate that businesses perceive a greater importance and have made greater progress in the implementation of the marketing concept vis-à-vis university schools of business as perceived by their academic vice-presidents, deans, and marketing department chairs. If, as previous research has found, organizations can improve their effectiveness by increasing levels of market orientation, university schools of business would seem to have ample opportunity to improve.

As the higher education administrators reported lower levels of market orientation in their organization than did their business counterparts, a significant opportunity would seem to exist for schools that will put more effort into their market orientation. As students of the university may be viewed as the most visible of the numerous markets served, market orientation efforts focused at students would seem to have the potential for the fastest and highest payoff. Examples of such payoffs might include:

1. An increase in enrollment within the business school

2. An increase in the hit rate (increase in percent of applicants that actually enroll)

3. An increase in the number of business/marketing majors

4. An increase in the retention rate of current business/marketing students

5. An increase in future giving by alumni

6. An improvement in rankings by outside organizations

Payoffs expected if more efforts were put into market orientation toward employers of students may include:

1. An increase in the number of employers hiring business/marketing graduates

2. An increase in total business/marketing students placed in jobs upon graduation

3. An increase in the number of internship programs available to business/marketing students

4. Enhancement of the academic programs via input from employers

5. An increase in the number of endowed chairs/professorships funded by employers

In view of Narver and Slater (1990) and Kohli and Jaworski (1993) findings that enhanced levels of market orientation will improve the competitive advantage of organizations, business schools appear to be organizations ripe to take advantage of the market orientation concept. Focus on creating market orientation culture should serve both schools and their various stakeholders in more effectively achieving the school mission.

Our conclusions are tempered by the finding of Noble, Sinha, \& Kumar (2002) and Haugland, Myrtveit, \& Nygaard (2007) that there appears to be no single strategic orientation that leads to superior performance in every case and as previously stated, building a market orientation culture within an organization is not a quick fix but rather a continuous process.

\section{FUTURE RESEARCH}

The research we report suggests several needs for additional research. For example, research should be undertaken to investigate if higher levels of market orientation toward students actually, rather than theoretically as reported here, leads to or is at least correlated with higher levels of organizational performance. Also, research should be undertaken to examine the impact or influence that variables such as size of a school, school affiliation (AACSB, ACBSP, or neither), admission standards, placement efforts, or recruiting efforts have on market orientation. Additionally, research on other stakeholders associated with schools of business would be useful. Such research would further our understanding of the market orientation construct and its application to higher education. 
Finally, we believe research in organizational culture including that of market orientation should be conducted in other non-profit organizations. Of particular interest would be an expansion of this line of research into other areas of higher education, into governmental agencies that provide services to the public, and into the non-profit side of the healthcare industry.

\section{AUTHOR INFORMATION}

Robert L. Webster earned a DBA from Louisiana Tech and is a Certified Government Financial Manager CGFM). He currently holds the George Young Chair of Business and is the Chair of the Accounting Department at Ouachita Baptist University in Arkadelphia, Arkansas.

Kevin L. Hammond earned a DBA from Louisiana Tech and is a tenured marketing professor at the University of Tennessee at Martin. He also serves as the MBA coordinator for the university.

James C. Rothwell serves as the Assistant Dean of the Business School at Ouachita Baptist University. He is a Certified Public Accountant and has served in several internal audit positions.

\section{REFERENCES}

1. Armstrong, J. S. \& Overton, T. S. (1977) Estimating nonresponse bias in mail surveys. Journal of Marketing Research, 14 (August), 396-402.

2. Barksdale, H. C. \& Darden, B. (1971) Marketers attitude toward the marketing concept. Journal of Marketing, 35 (October), 29-36.

3. Bentler, P. M. (1990) Comparative fit indexes in structural models. Psychological Bulletin, 107, 238-246.

4. Bentler, P. M. \& Bonett, D. G. (1980) Significance tests and goodness of fit in the analysis of covariance structures. Psychological Bulletin, 88, 588-606.

5. Berdie, D. (1989) Reassessing the value of high response rates to mail surveys. Marketing Research, 1, 5264.

6. BNQP (2005), "Baldrige Education Criteria for Performance Excellence," Baldrige National Quality Program, www.quality.nist.gov/Education_Criteria.htm.

7. Browne, M. W. \& Cudeck, R. (1993) Alternate ways of assessing model fit. In Bollen, K. A. \& Long, K. S. (Eds.) Testing structural equation models. Newbury Park, California: Sage, 136-162.

8. Browne, M. W. \& Mels, G. (1992) RAMONA User's Guide. The Ohio State University, Columbus, Ohio.

9. Churchill, G. A. (1979) a paradigm for developing better measures of marketing constructs. Journal of Marketing Research, 16 (February), 64-73.

10. Dwyer, F. R., \& Welsh, M. A., (1985) Environmental relationships of the internal political economy of marketing channels. Journal of Marketing Research, 22, (November), 397-414.

11. Felton, A. P. (1959) Making the marketing concept work. Harvard Business Review, 37, (July-August), 5565.

12. Hammond, K L., Webster, R. L., \& Harmon, H. A., (2006) Market orientation, top management emphasis, and performance within university schools of business: implications for universities. Journal of Marketing Theory and Practice, Winter, Vol. 14, No. 1, 69-85.

13. Haugland, S.A., Myrtveit, I., \& Nygaard, A. (2007) Market orientation and performance in the service industry: A data envelopment analysis. Journal of Business Research Vol. 60 No. 11, Nov., 1191-1197.

14. Houston, F. S. (1986) The marketing concept: what it is and what it is not. Journal of Marketing, 50 (April), 81-87.

15. Hunt, S. (1990) Commentary on an empirical investigation of a general theory of marketing ethics. Journal of the Academy of Marketing Science, 18, (Spring), 173-177.

16. Jaworski, B. J. \& Kohli, A. K. (1993) Market orientation: antecedents and consequences. Journal of Marketing, 57 (July), 53-70.

17. Karathanos, D. \& Karathanos, P. (1996) The Baldridge education pilot criteria 1995: An integrated approach to continuous improvement in education. Journal of Education for Business, 71 (May/June), 272276. 
18. Kohli, A. K. \& Jaworski, B. J. (1993) Market orientation: the construct, research proposition, and managerial implications. Journal of Marketing, 54 (April), 1-18.

19. Kotler, P. (1980) Marketing Management: Analysis. Planning and Control, (4th ed.) Englewood Cliffs, NJ: Prentice-Hall, Inc.

20. Larson, R. \& Catton, W., Jr. (1959) Can the mail-back bias contribute to a study's validity? American Sociological Review, XXIV, 243-245.

21. Levitt, T. (1969) The Marketing Mode. New York: McGraw-Hill Book Company.

22. Marsh, H. W. \& Hocevar, D. (1985) Applications of confirmatory factor analysis to the study of selfconcept: first -and higher-order factor models and their invariance across groups. Psychological Bulletin, 97, 562-582.

23. McNamara, C. P. (1972) The present status of the marketing concept. Journal of Marketing, 36 (January), 50-57.

24. Morse, R. J. \& Flanigan, S. M. (2000) America's best colleges-how we rank them. U.S. News and World Report, (September 11), 104-105.

25. Narver, J. C., Park, S. Y. \& Slater, S. F. (1992) Market orientation, information, and marketing strategies. American Marketing Association Summer Educators Conference.

26. Narver, J. C. \& Slater, S. F. (1990) The effect of a market orientation on business profitability. Journal of Marketing, 54 (October), 20-35.

27. Noble, C. H., Sinha, R. J., \& Kumar, A. (2002) Market orientation and alternative strategic orientations: a longitudinal assessment of performance implications. Journal of Marketing, 66 (October), 25-39.

28. Peterson's Guide to Four Year Colleges, 2001, 31st ed. (2000) Lawrenceville, NJ: Peterson's/Thomson Learning.

29. Siguaw, J. A., Brown, G. \& Widing, R. E., II, (1994) The influence of the market orientation of the firm on sales force behavior and attitudes. Journal of Marketing Research, 31 (February), 106-116.

30. Slater, S. F. \& Narver, J. C. (1994) Does competitive environment moderate the market orientationperformance relationship? Journal of Marketing, 58 (January), 46-55.

31. Webster, R.L., Hammond, K.L., \& Harmon, H.A. (2005) Comparing market orientation culture of businesses and schools of business: an extension and refinement. Psychological Reports, 96, 377-382.

32. Wheaton, B., Muthen, B., Alwin, D. F., \& Summers, G. F. (1977) Assessing reliability and stability in panel models. In Heise, D. R. (Ed.) Sociological Methodology 1977. San Francisco: Jossey-Bass, 84-136. 


\section{APPENDIX}

15 of 30 Survey Questions Sent to Marketing Department Chairs, Business School Deans, and Academic VicePresidents of AACSB

Schools of Business Administration

1. Our objectives are driven by satisfaction of our students.

2. We measure satisfaction of our students systematically and frequently.

3. Those responsible for recruiting students regularly share information within our business school/institution concerning competitor's strategies.

4. Our market strategies (such as recruiting and retention) are driven by our understanding of the possibilities for creating value for our students.

5. We respond rapidly to competitive actions that threaten us.

6. We constantly monitor our level of commitment and orientation to students.

7. University administration regularly discusses competitors' strengths and strategies.

8. All levels of administration understand how the entire institution can contribute to creating value for students.

9. We give close attention to service of students after enrollment.

10. Our strategy for competitive advantage is based on our understanding of our students needs.

11. We encourage other staff and faculty outside of recruiting/administration to meet with our prospective students and their parents.

12. All of our departments are responsive to and integrated in serving students.

13. Information on recruiting successes and failures are communicated across functions in the business school/institution.

14. We share information and coordinate resource use with other units in the institution.

15. We target potential students where we have, or can develop a competitive advantage.

Each question answered on a 7 point scale: 1=Not At All, 7=to An Extreme Extent. Questions 1, 2, 4, 6, 9, and 10 relate to the Customer Orientation construct/dimension, Questions 3, 5, 7, 11, and 15 relate to the Competitor Orientation, Questions 8,12,13, and 14 relate to Organizational Coordination. The Overall Marketing Orientation score is computed by averaging the mean scores of the other three sets of questions.

The other 15 Survey Questions noted in the paper were as above except the word "students" was replaced by the phrase "employers of students" 
NOTES 